\title{
Immigration, Welfare and Care in Portugal: Mapping the New Plurality of Female Migration Trajectories
}

\author{
Karin Wall* and Cátia Nunes** \\ *Institute of Social Sciences, University of Lisbon, Portugal \\ E-mail: karin.wall@ics.ul.pt \\ **Institute of Social Sciences, University of Lisbon, Portugal \\ E-mail: catia.nunes@ics.ul.pt
}

The role of migrant women as domestic and care workers is a main characteristic of the feminisation of migration to southern Europe. This article aims to understand how and why current patterns of female migration to Portugal are a key element, driving increased flows of domestic workers. The article focuses first on the path followed by Portugal in the fields of immigration, employment, welfare-state developments and care arrangements, and then presents results of a qualitative study on Brazilian immigrant women. Findings show that the new plurality of female migration trajectories is an important factor in explaining the rapid integration of immigrant women in the domestic sector. This does not mean, however, that a predominant 'migrant in the family' care model has emerged in Portugal. In contrast with other southern European countries, different policy perspectives and outcomes over the last three decades have made for a more diversified care model. National contexts in southern European countries must therefore be taken into account, since they provide particular conditions for the main forms and features of migrant domestic work.

\section{Introduction}

As in other European countries, the feminisation of migration flows in Portugal is related to the emergence of new labour market niches in the service sector. The high employment rates and long working hours of Portuguese women, the ageing population and the need to supplement the care work provided by formal services have led to a continued demand for domestic and care workers. In Portugal, it is mainly Portuguese women who are employed in this sector, but there are a growing number of immigrants, mostly Brazilian, Ukrainian and Cape Verdean women (Baptista, 2009).

The aim of this article is threefold: firstly, to map female immigration to Portugal, in the context of recent migration flows and the growing demand for care; secondly, to understand developments in the service sector, by examining the forms of domestic and care work and establishing the extent to which such work has become associated with migrants; lastly, drawing on qualitative research with Brazilian female migrants, ${ }^{1}$ to understand if and why their trajectories are diverging from the classic model of family migration, where the man comes first, the women and children later.

\section{Migration, welfare and care in Portugal}

Compared to its long emigration history, Portugal has only recently become a country of immigration. Labour migration flows from its former colonies in Africa, particularly 
Cape Verde, began during the sixties and increased following colonial independence in the seventies, partly making up for the mass emigration of Portuguese labour in previous decades. However, since the mid-eighties, Portugal has experienced an increasing and diversified flow of immigrants. While in-flows from the former colonies continued, there was also mass migration from Brazil and the Ukraine, as well as smaller flows from Moldavia, Russia, Romania, China, Pakistan and India (Pires, 2002). As a result, Portugal has become a receiving-country. ${ }^{2}$ The foreign resident population has increased sharply (to an estimated 440,000 in $2008^{3}$ ), and now represents almost 5 per cent of the total population. Migrants from Brazil $(106,961)$, Ukraine $(52,494)$ and Cape Verde $(51,353)$ represent the top three national groups of foreigners.

Within the foreign population, the number of women has always been high, but it has increased steadily during recent decades. Examining residence-permit data from 1980 to 2002, Peixoto (2006) found that the proportion of women increased from 40 per cent to 44 per cent, with an estimate of 47 per cent in 2008. In Portugal, the feminisation of migration flows (Morokvasic, 1984) must be analysed in the context of the different waves of immigration. Cape Verdean migration has traditionally had a high proportion of female migrants (51 per cent female in 2008), while migration from the Ukraine has been predominantly male followed by large-scale family reunification (52 per cent male in 2008), and Brazilian migration reveals the highest level of feminisation (54 per cent female in 2008). ${ }^{4}$

The increase in migration flows and their feminisation are aspects that place Portugal close to what some authors refer to as a distinctive Southern European immigration pattern (King, 2001; Bettio et al., 2006). Key features of this pattern include a rapidly ageing population, a familialistic Welfare State relying on family-based care rather than provision of services, a high proportion of illegal immigrants (making for cheap and flexible labour), the gender segmentation of immigrants' incorporation in the labour market, and the emergence of a new 'migrant-in-the-family' care model where immigrant women replace family carers. Taking the case of elderly care in Italy as an illustration, Bettio et al. show how the absence of services, coupled with generous cash transfers for the care of dependent persons over 65 and the active recruitment of migrant domestic workers, has led to the generalisation of an immigrant-based care model, which has become an affordable alternative for families across all income levels. ${ }^{5}$

Recent analysis of immigration, family policies and care regimes in Portugal, however, reveals commonalities and differences in relation to the Southern European pattern. Increased immigration and an average proportion of illegal migrants (OECD, forthcoming) are connected, as in other Southern European countries, to the demand for migrant workers at the lowest levels of the occupational structure, both in the building and industrial sectors and in the services sector. A second commonality is related to the fact that Portugal is characterised by a strong ideological commitment to the family and more family-centred living arrangements and obligations (Wall, 2005). For example, keeping the dependent elderly person at home for as long as possible, with some help from services, day centres or domestic employees, is still considered the best solution, even if institutionalisation is now envisaged as a normal option in cases of severe dependency (Torres et al., 2005; São José and Wall, 2006; São José, 2009).

However, three significant differences must be emphasised. First, the fact that the dual-earner model based on women's full-time participation in the labour market has long been the predominant model of family division of labour. This means that pressure 
for change in care regimes emerged early on, in particular during the eighties, due to the need for childcare services and services for elderly persons (Wall and Escobedo, 2009). Secondly, the 1974 Revolution led to changes in State responsibility for families, with strong support for women's full-time work and the provision of state-subsidised services to support working families (Wall et al., 2008a). Based on a logic of partnership between the State and non-profit institutions since the early eighties, emphasis on publicly subsidised services for the elderly has led to a steady increase in home-help services, day care centres and residential care-homes. Day centres have become especially important as they provide for frail elderly persons that need 'watching over' and daily care rather than full-time nursing (São José and Wall, 2006; Wall et al., 2008b). Data on take-up rates show that by 20043.5 per cent of elderly people over 65 were in day centres, another 3.8 per cent had home-help services and 3.7 per cent were in residential care-homes. ${ }^{6}$ Waiting lists continue to be long for places in subsidised residential care-homes, revealing that the care burden in low-income families with severely dependent persons is putting strong pressure on the expansion of affordable care-homes.

Thirdly, although data on immigrant care work are not comprehensive, recent studies have shown that in Portugal it is mainly upper-income families that resort to household and care services from migrants, in particular from co-residing minders (Wall et al., 2008). In the context of policies that do not actively recruit migrant domestic workers or provide generous cash benefits for elderly dependent persons, as in Italy, live-in or full-time care workers have only emerged as an important and affordable care solution for high-income families. As a result, rather than a predominant 'migrant in the family' model driven by transfer and immigration policies, the care deficit in Portugal has led to increasing diversification of care arrangements, to a mixed model including both homebased solutions and institutionalisation, both native and migrant carers, both publicly subsidised and private service provision. In summary, growing demand for care has undoubtedly led to changes in the care regime, but different political and economic contexts have made for different policy perspectives and outcomes (Wall and Escobedo, 2009).

\section{Domestic and care work in Portugal}

Domestic and care-work activities have always been highly feminised activities in Portugal. Although until the seventies the majority of Portuguese women did not work outside the home, many would look for a source of income by working as a domestic employee. For some, this would start at a very young age and within a live-in arrangement. Working in the domestic sector would often mean an opportunity for internal migration, from rural areas to the city (Wall, 1998).

Nowadays, the situation of female employment has changed drastically. Portuguese women work mainly outside the home and predominantly full time. Portugal has one of the highest rates of female activity in Europe (68.8 per cent according to Employment in Europe, 2008). With less time for household tasks, dual earner couples sometimes look for a third person to help take care of the household or dependent persons, usually another woman. There is also growing demand for care helpers in publicly subsidised services, which have increased strongly over the last two decades in response to an ageing population. Therefore, the domestic and care sector continues to be an area of the labour 
market where many Portuguese women, in particular those with lower educational levels, find work. ${ }^{7}$

Due to its prevalence in the Portuguese labour market and the specificities it entails, domestic work is regulated by specific legislation (type of contract, working hours, payment, entitlement to holidays, compulsory social security contributions, etc.). However, this does not mean that all employers and workers, in particular immigrant workers, are aware of existing regulations. Moreover, this is a sector where informal working relations are frequent, not only because the work is often carried out in private homes, but also due to the fact that it is a relatively easy way to find work in the informal economy.

In Portugal, working in the domestic and care sector can take different forms in terms of working hours, payment and other arrangements. There are women who only work for one private employer, either in a live-in arrangement or on a full-time basis (in both situations payment is defined on a monthly basis); women who work and are paid 'by the hour', dividing their working time between different private homes, and women working for institutions who provide care services or for companies who provide cleaning services. In these particular cases, the company acts as intermediary between the person requiring the service and the person providing it. The live-in arrangement, although very frequent until the seventies, has been decreasing, whereas the working by the hour regime has become the predominant form of work (Guerreiro, 2000). The latter, paid at 5 to 8 euros per hour in the main cities, allows women to build up monthly earnings well above the earnings provided by full-time work in other low-qualified jobs.

Research (Peixoto (ed.), 2006; Peixoto and Figueiredo, 2007) suggests that in Portugal the domestic sector is one of the main areas where immigrant women have been able to find a job, not only because there is demand for workers in this sector, but also because it is becoming less attractive for Portuguese workers, in particular in the form of 'live-in' work. Nevertheless, existing data seem to indicate that the sector is still dominated by Portuguese women, even if the proportion of immigrants has been on the increase over the last decade. Data from social security contributions of people working in the domestic sector show that the percentage of foreign women in this sector increased from 7 per cent to 11 per cent between 2002 and 2006 (Baptista, 2009). However, given the high levels of informality in this sector, especially in the case of immigrant women, we can expect the presence of immigrant women to be under-estimated. In summary, on the basis of the available data we can emphasise the growing presence of immigrant women in the sector, but it is not possible to say that immigrant women are replacing Portuguese women.

\section{Strategies and trajectories of Brazilian female care workers}

The focus on Brazilian female migration is important for three reasons. First, Brazilians represent the largest national group of migrants in Portugal. Secondly, Brazilian immigration has the highest level of feminisation, and initial studies of the Brazilian community suggested the growing importance of domestic and care work for female Brazilians (Peixoto, 2006; Padilla, 2007). Lastly, an exploratory research project on female migration in Portugal (Wall et al., 2008), focusing on the top three national groups (Brazil, Ukraine and Cape Verde), showed that although the pluralisation of female migration trajectories and growing feminisation occur in all three groups, it is above all the Brazilian care workers that families prefer, in particular for live-in care, due to language and 
perceived historical and cultural proximities (Nunes, 2009). In summary, in order to get a better insight into the interplay between domestic and care work, trajectories and increasing female migration in Portugal, an in-depth case study on Brazilian women immigrants emerged as a relevant research option.

\section{Data and method}

A total of 15 interviews were carried out with Brazilian immigrant women, following a semi-structured and open-ended approach. ${ }^{8}$ Interviews included topics focusing on the story of migration and identified a priori (such as the reasons and goals of migration, daily activities, difficulties of integration), but also adopted a more narrative approach, by asking interviewed women to talk freely about the experience of migration.

\section{Main types of trajectories}

Brazilian women's reasons to migrate are mainly related to labour market and financial factors, such as unemployment and the need to increase their income, in particular to pay off debts and to save up in order to achieve a specific goal, such as buying a house, paying for health expenses or improving living conditions. Care-work migration is seen as an opportunity to find a job with a higher salary, which will allow women to build 'a better life' for themselves and their families, either in Portugal or in the country of origin. Both 'live-in' and 'by the hour' forms of work are seen as opportunities to earn and save up, even if 'live-in' arrangements are perceived as a faster and more reliable way to do this. The wish to 'find a new life', linked to the idea of finding a new partner or rebuilding family life, may also emerge, particularly for single or divorced women.

The findings suggest a diversity of migration trajectories, revealing not only the different motivations and objectives that underpin the female care-worker's decision to migrate, but also the events and constraints that shape the trajectories. Brazilian female domestic and care workers tend to migrate 'alone', leaving their family (partner and/or children) in the country of origin, 'before' their husband/partner, or 'at the same time' as their partner and/or children. Analysis of women's discourses revealed differential dynamics of migration, which we classified into four main types of trajectories (Table 1). ${ }^{9}$

(1) 'Intensive saving' within a short stay - always lone women

Women care workers included in this trajectory have a well-defined migratory project. The main aim is to work intensively for a few years, to save up and to go back as soon as possible. All of these care workers are single or separated women who, when they have young children, leave them in the country of origin. Live-in domestic and care work is experienced as a fast track into the labour market and a way to save money.

This is the case of Neuza, a 23-year-old single mother who migrated alone, leaving a six-month old child in Brazil in the care of her mother. Before migrating, she lived with her mother, and was unemployed, only earning some money selling hand-made dolls. Neuza decided to come to Portugal shortly after her child was born. She needed money to support her daughter and, if possible, to renovate her mother's house. She arrived in Lisbon in October 2005 and went to work as a live-in domestic employee for an upperclass family, also caring for a 93-year-old elderly person. Neuza came to replace a friend 
Table 1 Migration trajectories of Brazilian women in Portugal

\begin{tabular}{|c|c|c|c|c|}
\hline & $\begin{array}{l}\text { 'Intensive saving' within short } \\
\text { stay }\end{array}$ & $\begin{array}{l}\text { 'A new life' within long-term } \\
\text { migration }\end{array}$ & 'Joint conjugal' & 'Women first' \\
\hline Trajectory & $\begin{array}{l}\text { Women migrate alone, } \\
\text { leaving children in country } \\
\text { of origin }\end{array}$ & $\begin{array}{l}\text { Women migrate alone - } \\
\text { some leave children and } \\
\text { some come with children }\end{array}$ & $\begin{array}{l}\text { Women migrate along with } \\
\text { husband/partner. }\end{array}$ & $\begin{array}{l}\text { Women migrate first, and the } \\
\text { husband and children } \\
\text { follow later. }\end{array}$ \\
\hline $\begin{array}{l}\text { Project and } \\
\text { objectives }\end{array}$ & $\begin{array}{l}\text { Well-defined project of } \\
\text { intensive saving. Women } \\
\text { plan to save up in order to } \\
\text { accomplish their objective } \\
\text { (e.g. buy/build house, pay } \\
\text { off debts, send money) }\end{array}$ & $\begin{array}{l}\text { Women decided to leave the } \\
\text { country of origin for a long } \\
\text { period of time They intend } \\
\text { to build a new life - find } \\
\text { better paid jobs, improve } \\
\text { living conditions, find a } \\
\text { partner }\end{array}$ & $\begin{array}{l}\text { Couple migrates together to } \\
\text { start a new life abroad or as } \\
\text { the fastest way to } \\
\text { accomplish their goals (e.g. } \\
\text { pay off debt). They reject the } \\
\text { idea of conjugal separation } \\
\text { inherent in a classic } \\
\text { reunification trajectory }\end{array}$ & $\begin{array}{l}\text { Challenging the classic } \\
\text { reunification model, } \\
\text { women take the initiative } \\
\text { of finding a job abroad to } \\
\text { ensure economic stability } \\
\text { for the family. }\end{array}$ \\
\hline Planning & $\begin{array}{l}\text { To stay for a few years - the } \\
\text { idea is to save up money } \\
\text { and quickly return }\end{array}$ & $\begin{array}{l}\text { Life plan is to stay on in the } \\
\text { host country (for some, } \\
\text { indefinitely). }\end{array}$ & $\begin{array}{l}\text { Some couples plan a short } \\
\text { stay, while others intend to } \\
\text { stay on. }\end{array}$ & $\begin{array}{l}\text { To stay on in receiving } \\
\text { country }\end{array}$ \\
\hline
\end{tabular}


of hers who was leaving this job. She has no contract, and all of the working conditions are established informally with her employer. She works from 8.30 am until 9 pm and has two days off. With a salary of 500 euros, she is paying off her debts in Brazil (a bank loan for her plane ticket) and sending money to her mother. She hopes to be able to pay off her debt in one year and then intends to start saving some money for the house. If all goes well, she will stay in Portugal for only three years.

Although working as a domestic employee and taking care of an elderly person was the job opportunity that brought Neuza to Lisbon, several aspects of the work fit in with her personal goals. Neuza recognises that the live-in arrangement has some major advantages, in particular for her migration project, because she is able to save up more money as she has fewer expenses.

Yes, I have a good salary. It's not bad. And also because I am here in the house of Mrs. L., and the way they treat me, it's also very good. And I don't spend a lot of money, because for housing I stay here, and food is also from here.

Illustrating the argument of Lutz concerning the special relationship between employers and domestic employees, which tends to be highly personalised and characterised by mutual dependency (2008: 1), Neuza feels that, if she decides to leave, she will have to find someone to replace her. This was how she was able to find work in Portugal and she feels it is important to maintain this scheme, not only to give someone else an opportunity to come, but also to fulfil her feelings of obligation toward her employer. The existence and reproduction of what we might call substitution social networks are important to explain how many immigrant women are able to find a job so easily in the domestic sector.

So, I wanted to come to Portugal, but I said to my sister that I would only come if I had a job, if I arrived and already had a job. And so my sister talked to I. [the friend Neuza came to substitute] and then she talked to Mrs. L., that she was leaving but that she would find someone to substitute her ...' I am not going to leave Mrs. L. without someone to take care of Mrs. J...', and she worried about that. And I'd never do that either, not me.

(2) 'A new life' within long-term migration - lone women on arrival, often cohabiting today

Replacing another immigrant woman in care work was also how Dalila, a 31 -year-old single woman, was able to find a job in Portugal. She came to Portugal to replace her sister, who decided to return to Brazil. Although Dalila was unemployed at the time, coming to Portugal was also an opportunity to get away from a difficult relationship and start a new life. So Dalila illustrates a different type of trajectory. While in the case of Neuza there was a clearly defined objective within a short-term project, Dalila's main reason for migrating is to find a better life and to stay on in the host country. She arrived in Portugal in 2001 and at first worked in a live-in arrangement, taking care of the household tasks and of an elderly person, in the house where her sister used to work. Her situation changed when the elderly person passed away. Dalila then began to work as a domestic employee 'by the hour' during the morning and in a café during the afternoon and at weekends. She has no days off, but she is pleased to be earning around 840 euros per month. Dalilas's legal situation also differs from that of Neuza, as she has a work contract (in her job as 
domestic worker in a private home) and was able to 'legalise' her situation and to get a residence permit. She is buying a house in Portugal with her partner, a Portuguese citizen, with whom she currently lives. Her intention is to stay in the country indefinitely and all of her 'investments' (financial and emotional) reflect this option.

My life is here now ... Ah, the fact that I have a job is a big difference for me. I have been doing this job [domestic work] for four years now and that is great... And, as I always say, I'm going to stay as long as everything goes well.

(3) 'Joint conjugal' trajectory - married women, arriving with partner

Immigrant women in this type of trajectory are married or cohabiting and may or may not have dependent children. Joint conjugal migration means that the two members of the couple migrate together, even if the migratory project is related to the woman's capacity to find well-paid domestic or care work in the receiving country. These are dual-earner couples in which the wife has an important breadwinning role.

The case of Ângela illustrates this type of trajectory. Ângela is a 39-year-old married woman who migrated with her husband. The couple has a well-defined project of intensive saving within a short-term stay, their main motivation being to save up in order to pay off a bank loan in Brazil. Their two children, aged 23 and 16, stayed in Brazil on their own (the oldest son takes care of his brother). Although the couple decided to come together, Ângela considers that the decision to migrate was mainly her idea:

My husband and I built a house and we lost our first house and it was very very difficult. We began to build another house and when we finished we had a large debt to the bank. The debt was huge and we were having difficulties in paying for it so I decided 'let's go, both of us, I can't lose this house, I have my children' ... So we both came, because it would not be possible for me to come alone, because my husband is like that, he depends a lot on me. I think women, even though people say that men usually have the initiative, I don't think this is true, it is often the woman who decides. So, I came to Portugal.

Soon after arriving, Ângela was able to find a job as a domestic employee working in different private homes and being paid by the hour. She was able to find work through informal contacts. She earns 6 euros per hour and is able to earn around 1,000 euros per month. In all the different homes where she works, the working conditions, in terms of hours and payment, were established informally. This and her 'irregular' situation are not perceived as disadvantages. As she puts it, there are no clear advantages in changing her situation, as she does not intend to stay in Portugal for a long period of time. Moreover, she saves more money by not contributing to social security.

During the first year, Ângela and her husband (a gardener) worked seven days a week in order to pay for their travel expenses. It took them another two years to save up money to pay for their house. Up until February 2007, the couple stayed in Portugal together, then her husband went back to Brazil. Ângela stayed on for a few months to save up more money and only returned to Brazil in August 2007. The decision regarding Ângela's stay in Portugal was related to the fact the she was earning more than her husband as a domestic employee 'by the hour'. This fact is perceived by Ângela as reinforcing her economic independence and the central place she occupies within the household as an important breadwinner. 
I have always worked, I want to have my own money, for sure, but I am very independent, I never depended on my husband here, in fact it was the other way around, he depended on me.

(4) 'Women first' trajectory within a long-term stay - married women, alone on arrival, today with family

Antónia works by the hour, but her migration trajectory was different. She was the first member of her family to migrate, and her trajectory shows an inversion of the classic family reunification model. Antónia is a 47-year-old married woman who decided to migrate to Portugal with her adolescent daughter in 2002. Her main reasons for migrating were financial, as she was unemployed and had to pay off some family debts, and was also family-focused, with migration seen as a way of helping her daughter to recover from a recent problem of drug-addiction. Although Antonia only went to school a few months and was a manual worker in Brazil, she has always been the main breadwinner of the family, and even when she arrived in Portugal, she felt it was her responsibility to send money to her husband in the country of origin.

In Portugal, she knew it would be easier to find a job as a domestic employee. However, as she had no personal contacts, in order to find a job she put an advertisement in a newspaper. She was able to find a job two weeks later, working in a private home. Since then, she has been working for several employers 'by the hour', and manages to combine this with two more jobs working in the kitchen of a restaurant and cleaning in a pharmacy. Meanwhile, the family decided to come, arriving two years later, and initially relying on Antónia's income.

\section{Conclusion}

In this article, we have explored the diversity of female migration trajectories in Portugal. We have focused on immigrant women working in the domestic and care sector, thereby emphasising the linkages between female migration and domestic work in order to capture a variety of trajectories. Our evidence can be only tentative, as the qualitative research is based on 15 in-depth interviews and therefore cannot provide a comprehensive view of immigrant women in the domestic and care sector. However, our findings do suggest that female labour migration trajectories related to this sector have become more diversified over the last two decades. The classic reunification trajectory where the husband migrates first still exists in current migration flows, but we now have to address a new plurality of trajectories: women who come to work in the domestic and care sector seem to migrate more often alone, as single or divorced women, with their partners or children, or before them.

In Portugal, the increased participation of women in the labour market in a full-time regime, the rapid ageing of the population, and Portuguese workers' rejection of livein arrangements are important driving forces behind contemporary female immigration flows. Mounting demand for care since the eighties has helped to maintain a market for well-paid domestic employees and carers working 'by the hour', to increase publicly subsidised and private provision of services, and to swell the informal market for livein, around-the-clock carers only afforded by upper-income households. However, it is also true that mounting demand and Portuguese families' growing care burden would probably not have sufficed, on their own, to generate the integration of female migrants into these labour market niches. The new plurality of female migration trajectories, in the 
context of mass migration from Brazil and some other countries (Ukraine, Cape Verde), has also allowed for a rapid and successful integration of immigrant women in the care and domestic sector.

Diversification in female migration trajectories seems to be linked to three important factors: first, to major shifts in gender roles in the sending country. For different reasons and in different contexts, most women who come to Portugal to care or undertake domestic work were employed or had already been employed before migration. In the receiving country, they are looking for new employment opportunities and expect to be important or main breadwinners, especially when they have children.

Secondly, diversification also appears to be shaped by changes in family patterns in the sending countries, in particular by the increase in lone motherhood and divorce and by female survival strategies. Lone motherhood is related not only to the rise in separation and divorce, but also to the increase in male poverty and unemployment, which reinforces women's role as lone parents and breadwinners. Job opportunities in the domestic and care-work sector in Europe thus represent an important way out in the struggle for survival and better living conditions for children born out of wedlock or belonging to households where the mother is the main or sole breadwinner.

Lastly, there seems to be a strong connection between Brazilian female Portuguesespeaking migration, 'live-in' arrangements as a stepping stone into employment in the sector, and what we have described as 'substitution social networking', in which the care worker takes it upon herself to ensure the continuity of the care arrangement on behalf of the employer. Alongside language skills, higher educational levels and cultural proximity, which are of some importance in the acceptance of Brazilian immigrant women in private homes, the social networking strategy creates a stronger connection between this national group of immigrants and families employing domestic and care workers. In the frame of a global economic context where rich and demographically ageing countries need more domestic and care workers, networking and changing gender and family roles may be therefore considered as important intermediary driving forces of the feminisation of immigration.

\section{Notes}

1 Data in this article come from an EC research project, Female Migration Vision, coordinated by Fondazione Brodollini and Karin Wall.

2 Immigration policies in Portugal have undergone several changes since the mid-nineties (Costa, 2004). Although quotas are in place to regulate the entrance of foreigners, a large number of immigrants have entered illegally or with a tourist visa. The estimated percentage of undocumented immigrants is 20 per cent (OECD, forthcoming). Over the last two decades, Portugal has undertaken five processes of regularisation. In 2001, regularisation included a new type of visa, the staying permit, valid for one year and renewable for another four, which allowed for large-scale regularisation of Eastern European and Brazilian migrants. In the case of Brazilian immigration, a bi-lateral regularisation agreement ('Lula's agreement') was also established. In the context of regularisation schemes, there have been no quotas for domestic/care services.

3 Portuguese Immigration Statistics (www.sef.pt).

4 See endnote 3.

5 See also Anderson (2000), Parreñas (2001), Enrenreich and Hochschild (2003).

6 MTSS (2006) (www.cartasocial.pt).

7 Census data (www.ine.pt) on domestic workers in private homes indicate that in 2001 the domestic work sector represented 2.3 per cent of the total active population, down from 3.0 per cent in 1991 and 
3.1 per cent in 1981. Those working for companies are excluded from the data, yet they represent a growing proportion of workers in the sector (Guerreiro, 2000). It is important to take into account, therefore, that the decline in the number of domestic workers in private homes is being compensated for by some transfer of workers to small firms providing cleaning and care services.

8 Interviews were conducted in private homes and in migrant associations, in Lisbon, between January 2006 and July 2007. Interviews lasted on average two hours and were transcribed verbatim.

9 The classic family migration model, in which men come first and women and children later, was not found. This is not to imply that it does not exist. Instead, given Brazilian women's easy access to work in the domestic and care-work sector, it is likely to be one strategy amongst others rather than the predominant type of migration trajectory.

\section{References}

Anderson, B. (2000), Doing the Dirty Work? The Global Politics of Domestic Labour, London: Zed Books.

Baptista, P. (2009), 'Imigração e Trabalho Doméstico: o Caso Português', Masters Dissertation, ISEG-UTL, Lisbon.

Bettio, F., Simonazzi, A. and Villa, P. (2006), 'Change in care regimes and female migration: the "care drain" in the Mediterranean', Journal of European Social Policy, 16, 3, 271-85.

Costa, P.M. (2004), Políticas de Imigração e as Novas Dinâmicas da Cidadania em Portugal, Lisbon: Instituto Piaget.

Ehrenreich, B. and Hochschild, A. R. (eds.) (2003), Global Woman: Nannies, Maids and Sex Workers in the New Economy, New York: Henry Holt \& Company.

Guerreiro, M. D. (2000), 'Employment, family and community activities: a new balance for women and men', European Foundation for the Improvement of Living and Working Conditions, http://www.eurofound.europa.eu/pubdocs/2000/120/en/1/ef00120en.pdf.

King, R. (ed.) (2001), The Mediterranean Passage: Migration and New Cultural Encounters in Southern Europe, Liverpool: Liverpool University Press.

Lutz, H. (ed.) (2008), Migration and Domestic Work: A European Perspective on a Global Theme, Hampshire: Ashgate.

Ministério do Trabalho e da Solidariedade Social (2006), Carta Social, MTSS: Gabinete de Estratégia e Planeamento.

Morokvasic, M. (1984), 'Birds of passage are also women', International Migration Review, 18, 886-907.

Nunes, C. (2009), 'Percursos Migratórios no Feminino: Mulheres Brasileiras em Portugal', Masters dissertation, FCSH-UNL, Lisbon.

OECD (forthcoming), Irregular Migration in OECD Member States: Nature, Profiles and Policies, Organisation for Economic Co-operation and Development.

Padilla, B. (2007), 'A imigrante brasileira em Portugal: Considerando o género na análise', in J. Malheiros (ed.), Imigração Brasileira em Portugal, Lisbon, ACIDI, pp. 113-34.

Parreñas, R. (2001), Servants of Globalization: Women, Migration and Domestic Work, Stanford, CA: Stanford University Press.

Peixoto, J. (ed.) (2006), Mulheres Migrantes: Percursos Laborais e Modos de Inserção Socioeconómica das Imigrantes em Portugal, Lisbon: SOCIUS-ISEG.

Peixoto, J. and Figueiredo, A. (2007), 'Imigrantes brasileiros e o mercado de trabalho em Portugal', in J. Malheiros (ed.), Imigração Brasileira em Portugal, Lisbon: ACIDI, pp. 87-112.

Pires, R. P. (2002), 'Mudanças na imigração: uma análise das estatísticas sobre a população estrangeira em Portugal 1998-2001', Sociologia, Problemas e Práticas, 39, 151-66.

São José, J. (2009), 'Cuidar de um Familiar Idoso Dependente', Ph.D. dissertation, ICS-UL, Lisbon.

São José, J. and Wall, K. (2006), 'Trabalhar e Cuidar de um Idoso Dependente', Cadernos Sociedade e Trabalho, 7, 119-54.

Torres, A., Silva, F. V., Monteiro, T. L. and Cabrita, M. (2005), Homens e Mulheres entre Família e Trabalho, Lisbon: CITE. 
Wall, K. (1998), Famílias no Campo: Passado e Presente em duas Freguesias do Baixo Minho, Lisbon: D. Quixote, Colecção Portugal de Porto.

Wall, K. (2005), Famílias em Portugal: Percursos, Interacções, Redes Sociais, Lisbon: Imprensa de Ciências Sociais.

Wall, K. and Escobedo, A. (2009), 'Portugal and Spain: two pathways in Southern Europe', in S. Kamerman and P. Moss (eds.), The Politics of Parental Leave Policies, Policy Press, pp. 207-26.

Wall, K., Nunes, C. and Matias, A. R. (2008), 'Mulheres Imigrantes e Novas Trajectórias de Migração: Um Croché Transnacional de Serviços e Cuidados no Feminino', in M. V. Cabral, K. Wall, S. Aboim and F. C. Silva (eds.), Itinerários. A Investigação nos 25 anos do ICS, Lisbon: Imprensa de Ciências Sociais, pp. 603-22.

Wall, K., Samitca, S. and Leitão, M. (2008a), 'Work-family policies in Portugal', ICS Working Paper, Imprensa de Ciências Sociais, Lisbon.

Wall, K., Samitca, S. and Leitão, M. (2008b), 'Elderly care in portugal: working and caring for an elderly person', Final Report Woups Project, Imprensa de Ciências Sociais, Lisbon. 